\title{
Influence of restoration and succession on bottomland hardwood hydrology
}

\author{
R.K. Kolka ${ }^{a, *}$, J.H. Singer ${ }^{b}$, C.R. Coppock ${ }^{b}$, W.P. Casey $y^{b}$ C.C. Trettin ${ }^{b}$ \\ a Department of Forestry, University of Kentucky, Lexington, KY 40546, USA \\ b Center for ForestedWetlands Research, USDA Forest ServiceCharleston, SC 29414, USA \\ Received 19 March 1999; received in revised form 19 May 1999; accepted 15 September 1999
}

\begin{abstract}
Abs tract
The hydrologic pathways of four bottomland hardwood wetland sites were investigated with transects consisting of nests of shallow wells and piezometers. Sites included a disturbed but recently restored system, two disturbed systems that are recovering naturally and a relatively undisturbed reference site. Water table elevations in both uplands and bottomlands were significantly higher in the reference site than in disturbed sites. Hydrologic budgets were developed that included throughfall inputs, upland inputs, bottomland interflow, bottomland losses to the stream and evapotranspiration (ET) losses. The recently restored bottomland had significantly higher throughfall and lower ET than the naturally recovering sites. Higher throughfall and lower ET is attributed to canopy manipulations that occurre d during restoration. Other hydrologic fluxes are relatively similar among the dis turbed sites. Reference site flow pathways were significantly different than those of the disturbed sites. Higher ET in the reference site is attributed to differences in canopies between the reference and disturbed sites. Higher upland inputs, bottomland interflow, and bottomland losses to the stream are the result of higher water tables in the reference site. Lower water tables in disturbed sites may be caused by the geomorphic changes that occurred during elevated flow periods prior to recovery. (C) 2000 Els evier Science B.V. All rights reserved.
\end{abstract}

Keywords: Hydrology; Water balance; Bottomland hardwoods; Wetland restoration

\section{Introduction}

Hydrology determines the establishment and ery maintenance of specific types of wetlands and wetland processes and is the most important factor that will influence the success of a wetland

* Corresponding author. Te1.: + 1-606-2574208, fax: I+ 606-3231031.

E-mail address :rkolk2@pop.uky.edu (R.K. Kolka). restoration (Clewell and Lea, 1989; Mitsch and Gosselink, 1993). Assessment of hydrologic recovery following wetland restoration/creation generally based on water table elevations measured in shallow groundwater wells (Myers et al., 1995; Niswander and Mitsch, 1995; Wils on and Mitsch, 1996). The depth, duration, and periodicity of inundation in a wetland are often related to plant establishment, plant distribution and growth (Niswander and Mitsch, 1995; David, 1996; Dulo- 
hery et al., 2000), litter decomposition (Conner and Day, 1991) and important soil properties (Megonigal et al., 1993; Comerford et al., 1996).

Although water table information is important, more detailed hydrologic investigations assessing water sources and flow pathways can more fully elucidate important wetland processes. In bottomland hardwood systems, few studies have attempted to fully characterize the important pathways of the hydrologic cycle. Williams and Pinder (1990) found groundwater to be the dominant source of water to a bottomland stream on the Savannah river site in South Carolina. Dosskey and Bertsch (1994) estimated pathways of carbon transport using flow information derived from the Williams and Pinder (1990) study. Walton et al. (1996) found that river discharges dominated the wetland water fluxes in a bottomland hardwood site located on the Cache river in Arkansas.

Although not directly analogous to a restoration, the effect of timber harvesting in bottomlands has been shown to both increase (Aust et al., 1997) and decrease (Lockaby et al., 1997) water table levels following harvest. These effects are seen only for the first few growing seasons following harvest and water tables recover to preharvest or reference levels as stands naturally regenerate. We would expect more drastic vegetation impacts, such as those from thermal discharges, to have a longer lasting effect on the recovery of hydrology.

No studies of which we are aware have fully characterized the hydrologic cycle during the restoration of a bottomland hardwood system. Furthermore, no studies have compared the important components of the hydrological cycle in a recently restored system with those of naturally succeeding, similarly impacted sites and those of a mature, relatively unimpacted site. The objectives of our study were to (1) characterize the important hydrologic flow pathways in four bottomland sites, one restored, two naturally recovering, and one reference site and (2) compare key hydrologic parameters and pathways of flow across the successional gradient to determine the effect of succession and restoration on the water budgets of these sites.

\section{Materials and methods}

\subsection{Study sites}

For over 30 years the bottomland hardwood system of the Pen branch corridor and delta was used for the discharge of coolant water from a nuclear reactor at the Savannah river site (Fig. 1). Prior to reactor placement, flow in Pen branch was typically $0.28-0.57 \mathrm{~m}^{3} \mathrm{~s}^{-1}$. Reactor operations raised the flow to as much as $11.3 \mathrm{~m}^{3} \mathrm{~s}^{-1}$ with secondary coolant water temperatures ranging from $40-65^{\circ} \mathrm{C}$ (Nelson et al., 2000). When the reactor was retired in 1989, this high-temperature, elevated flow effluent had removed virtually all vegetation and eliminated the seed bank and root stock from the previous bottomland hardwood wetland. In 1992, the USDA Forest Service began efforts to accelerate the restoration of the Pen branch system to its previous bottomland hardwood state. Approximately $75 \%$ of the entire area (90 ha) was planted with trees using various site preparation techniques. Planting was done in strips with unplanted control strips between each planted area. Species were selected based on soil type and general hydrology in the floodplain corridor and delta (Nelson et al., 2000).

Results from hydrologic investigations in Pen branch (watershed area, $55 \mathrm{~km}^{2}$ ) are compared to Fourmile (watershed area, $57 \mathrm{~km}^{2}$ ) and Meyers branch (watershed area, $51 \mathrm{~km}^{2}$ ) creeks (Fig. 1). Fourmile creek had thermal impacts very similar to Pen branch (Nelson et al., 2000) and has been naturally recovering since 1985 . Meyers branch never received thermal effluents and is a relatively unimpacted, late-successional reference site.

\subsection{Hydrological monitoring}

Two study areas for hydrologic transects were established in Pen branch, one in an unplanted area, (Fig. 1, aera C), and one in a planted area, (Fig. 1, area D). Hydrologic transects were also installed at Fourmile creek and Meyers branch (Fig. 1). All sites are located at similar elevations $( \pm 5 \mathrm{~m})$ and occur on the Sunderland terrace of the Lower Coastal Plain physiographic province (Workman and McLeod, 1990). Transects were 

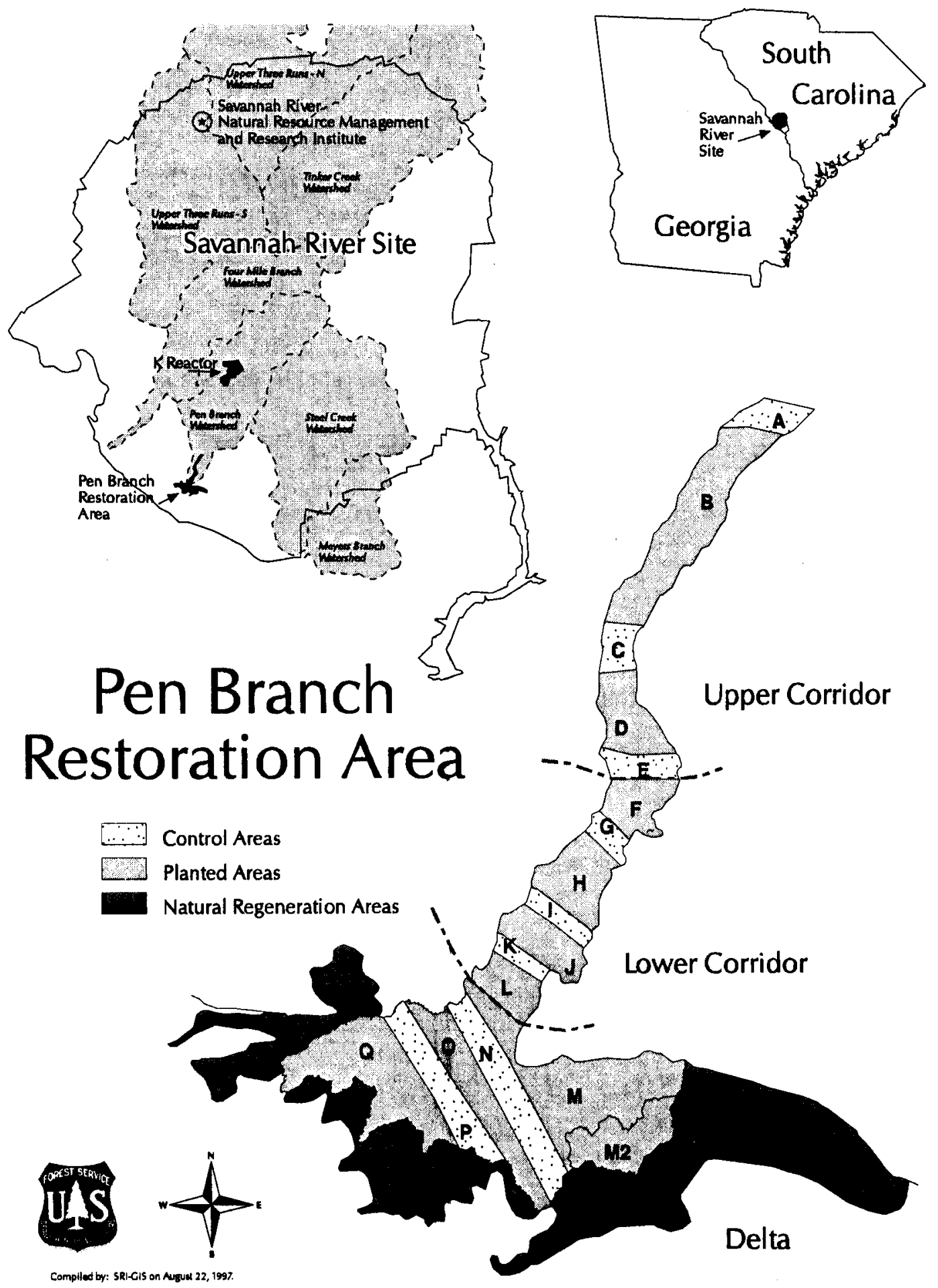

Fig. 1. Location of sites including Meyers branch, Fourmile creek and C and D areas in Pen branch. 
established in winter of 1996-1997, with weekly monitoring beginning in May of 1997 and proceeding through December of 1998. Data presented are for the 1998 calendar year. Hydrologic transects were designed to monitor representative flows in each system (Fig. 2). Three levels of flow were identified among the braided bottomland systems, (1) main channels, (2) intermediate channels, and (3) side channels (in decreasing order of flow volume). In each system, one main channel was identified and monitored. Numerous intermediate and side channels occur across the braided floodplains. Study areas in Pen branch $\mathrm{C}$ and Pen branch D each have one main, one intermediate and one side channel transect (Fig. 2). Fourmile creek and Meyers branch each have two main channel, one intermediate and one side channel transect. Results from our monitoring of a single intermediate and side channel from each site are applied to all similar channels across the floodplain to develop corridor flow estimates.

Hydrological transects are a series of intensively monitored plots arranged perpendicular to the bottomland corridor. Plots were located at the upland-bottomland and the bottomlandstream interfaces with the intent to study upland to wetland fluxes and wetland to stream fluxes (Fig. 2). Plots include shallow groundwater wells
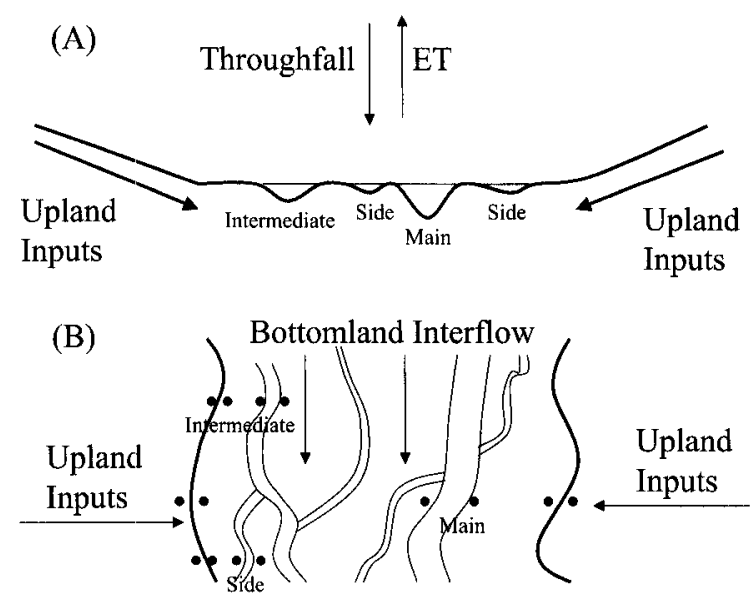

Fig. 2. Cross-sectional view (A) and aerial view (B) showing the well and piezometer placement design and the major hydrologic fluxes measured.
$(200 \mathrm{~cm})$ and a nested set of piezometers (50, $100,150,200 \mathrm{~cm})$. Piezometers were constructed of $2.5 \mathrm{~cm}$ diameter schedule 80 PVC tubing with the submerged end perforated and covered with nylon mesh that is secured by a PVC cap and duct tape. Piezometers were capped with bentonite clay at the soil surface. Groundwater wells were $5 \mathrm{~cm}$ diameter schedule 40 PVC tubes equipped with acute tips and slotted along their entire submerged length.

Main channel transects include six nests and span the entire width of their respective corridors. Intermediate and side channel transects include four nests and extend from the channel to the nearest upland (Fig. 2). Recording wells were installed in all streams (14 locations) to measure stage height. Stage height-streamflow relationships were measured seasonally to develop a rating curve for each stream site. Our streamflow estimates were compared to USGS streamflow measurements upstream from our sites to check for consistency. Recording wells were also installed next to a subset of well and piezometer nests in all four sites (six locations) to semi-continuously measure groundwater levels. Recording wells in both the stream and the bottomland measured water levels at 3-h intervals.

Open precipitation volume was monitored in a powerline opening between Pen branch and Fourmile creek. Transects of three throughfall collectors were placed near to each main channel transect and in one representative upland area near Pen branch. Oil was added to these collectors to prevent evaporation. Open precipitation and throughfall volume were measured weekly throughout the duration of the study.

All wells, piezometers, recording wells and throughfall collectors were surveyed for elevation with a laser level and referenced to a known elevation. Soils were described at a subset of well/piezometer nest locations. Pump/slug tests were performed on a subset of upland and bottomland wells and piezometers in Meyers branch to estimate saturated hydraulic conductivity. Saturated hydraulic conductivity from these tests was applied to similar soil layers across sites. 
Table 1

Mean water table depths for Pen branch, Fourmile creek, and Meyers branch ${ }^{a}$

\begin{tabular}{lll}
\hline Site & Upland (cm) & Bottomland $(\mathrm{cm})$ \\
\hline Pen branch C & $-82.3 \mathrm{a}$ & $-26.9 \mathrm{a}$ \\
Pen branch D & $-47.9 \mathrm{~b}$ & $-28.2 \mathrm{a}$ \\
Fourmile creek & $-72.5 \mathrm{a}$ & $-22.7 \mathrm{a}$ \\
Meyers branch & $-35.0 \mathrm{c}$ & $-13.8 \mathrm{~b}$ \\
\hline
\end{tabular}

${ }^{a}$ Significant differences noted $(P<0.05)$.

\subsection{Data analyses}

Mean water table and piezometer depths for both bottomland and upland were calculated both annually and seasonally. Duration of flooding was estimated with the percentage of days in which the mean water table elevation was above the soil surface. Weekly throughfall volumes were summed for annual and seasonal totals. Bottomland streamflow is the result of measured main channel, intermediate and side channel flow. Additional intermediate and side channels that were not measured were counted and classified. Flow measured in representative intermediate and side channels were applied to ones not measured. Growing season evapotranspiration (ET) was estimated with bottomland recording well data for selected time intervals between 21 May and 17 June 1998. Dates were selected when no rainfall occurred and declining groundwater depths could be attributed to ET. Evapotranspiration rates were calculated by measuring the daily amplitude of water table depth change and converting to a volume basis, assuming $50 \%$ soil porosity. Soil layer contributions from uplands to the bottomland and from the bottomland to the stream are the result of piezometric surface gradients between piezometers at the upland-bottomland and bottomland-stream interfaces and estimated saturated hydraulic conductivity (Fig. 2). Individual soil layer contributions were summed for seasonal fluxes. Bottomland interflow is flow-through the bottomland, parallel to the stream corridor from up-gradient bottomland sources (Fig. 2). Bottomland interflow was calculated with an estimated profile hydraulic conductivity, and mean water table gradients from the furthest comparable set of wells among transects in each location. Annual water budgets are the result of throughfall inputs, upland groundwater inputs to the bottomland, bottomland inputs/outputs to the stream, ET outputs, and bottomland interflow (Fig. 2).

\subsection{Statistics}

All water flux calculations were standardized to a 1.7 ha bottomland area, the size of our smallest study area (Pen branch C). Analyses were performed for both annual and seasonal distributions. Comparisons within and among sites were made using Student's $t$-tests.

\section{Results}

\subsection{Water table depth}

Mean water table depth for 1998 varied significantly among sites (Table 1). Among uplands, Meyers branch had the shallowest mean water table, followed by Pen branch D, Fourmile creek and Pen branch $\mathrm{C}$ which were similar. All bottomlands had significantly higher water tables than their respective uplands $(P<$ 0.05 ). Bottomland water table depth also was significantly different among sites with Meyers branch having the shallowest water table followed by Fourmile creek, Pen branch C and D which all had similar depths (Table 1). Water table depth varied by season with summer and fall water tables lower than in winter and spring for all sites (Fig. 3). Standard errors in Fig. 3 are related to the magnitude of fluctuation of the water table. Water table depth fluctuations were greater in upland sites than bottomland sites for Pen branch and Fourmile creek but were lower in Meyers branch. The Meyers Branch bottomland had greater fluctuations in the water table than either Pen branch or Fourmile creek. Flooded conditions were observed for $16 \%$ of the year in Meyers branch, followed by $9.3 \%$ in Fourmile, $2.6 \%$ in Pen branch $\mathrm{C}$ and $1.3 \%$ in Pen branch D. 


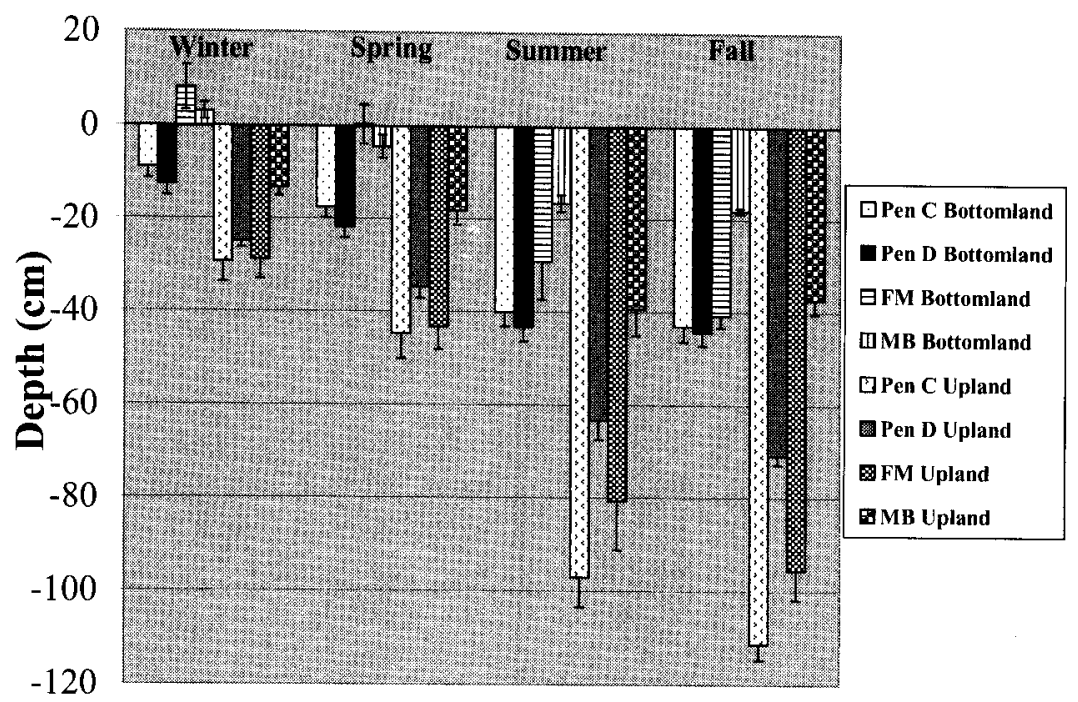

Fig. 3. Seasonal water table elevations for both upland and bottomland sites in Pen branch, Fourmile creek and Meyers branch (error bars are S.E.).

\subsection{Throughfall volume}

Open precipitation volume $(127.3 \mathrm{~cm})$ was similar to that measured by USGS stations in nearby Aiken, SC (129.6 cm) and Augusta, GA (119.6 $\mathrm{cm})$. Precipitation volume measured in Augusta, GA was 3.5\% above normal, indicating a relatively wet year. Precipitation was well above normal in winter, below normal in spring, near normal in summer and well below normal in the fall. Throughfall volume in Pen branch D was similar to open precipitation (Fig. 4). All other sites had significantly less throughfall than open precipitation $(P<0.05)$.

\subsection{Streamflow}

Bottomland streamflow in the planted area of Pen branch (Pen D) was significantly higher than other sites (Table 2). The unplanted area in Pen branch (Pen C) had similar streamflow to both Fourmile creek and Meyers branch (Table 2). Seasonally, streamflow decreased throughout the year in both Pen branch sites and Fourmile creek (Fig. 5). Meyers branch streamflow decreased from winter to spring, rose in the summer, and decreased again in the fall (Fig. 5). Our mean

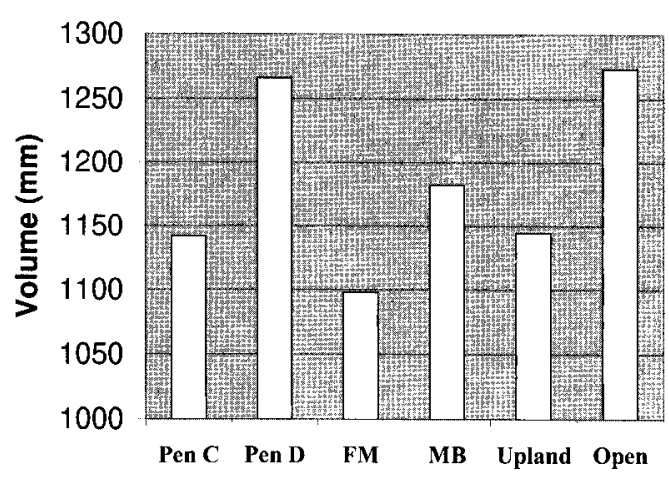

Fig. 4. Annual open precipitation and throughfall volume for sites in Pen branch, Fourmile creek and Meyers branch.

Table 2

Mean annual streamflow for Pen branch, Fourmile creek, and Meyers brancha

\begin{tabular}{ll}
\hline Site & Streamflow $\left(\mathrm{m}^{3} \mathrm{~s}^{-1}\right)$ \\
\hline Pen branch C & $1.21 \mathrm{bc}$ \\
Pen branch D & $1.70 \mathrm{a}$ \\
Fourmile creek & $1.14 \mathrm{c}$ \\
Meyers branch & $1.23 \mathrm{~b}$ \\
\hline
\end{tabular}

a Significant differences noted $(P<0.05)$. 


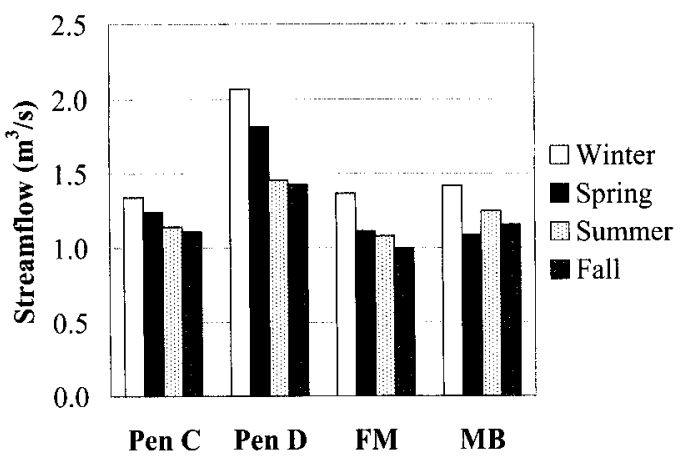

Fig. 5. Seasonal streamflow measurements for sites in Pen branch, Fourmile creek and Meyers branch.

annual streamflow measurements for 1998 compare well with those measured by the USGS in 1995 at locations several $\mathrm{km}$ upstream from our Pen branch and Fourmile sites (Westinghouse Savannah River Company, 1997). Mean annual streamflow measured by USGS is 1.6 and $1.1 \mathrm{~m}^{3}$ $\mathrm{s}^{-1}$ for Pen branch and Fourmile, respectively. Meyers branch is not monitored by the USGS and we are not aware of any other streamflow measurements performed in Meyers branch.

\subsection{Growing season evapotranspiration}

Evapotranspiration fluxes varied by site with Meyers branch having the greatest fluxes, followed by Fourmile creek, Pen branch $\mathrm{C}$ and Pen branch D (Table 3).

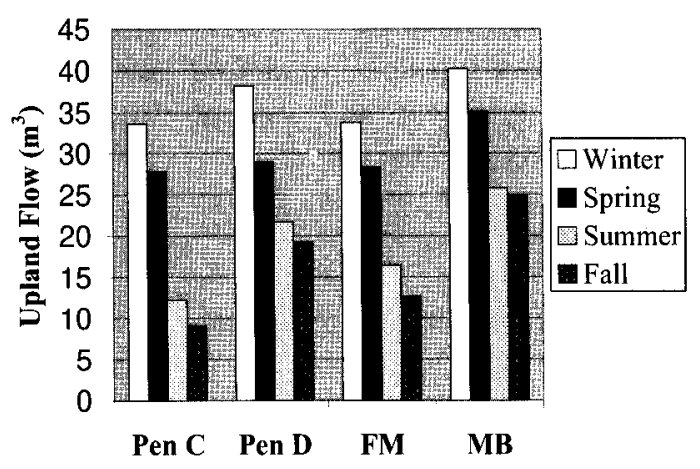

Fig. 6. Seasonal upland flow volume to Pen branch C, Pen branch D, Fourmile creek and Meyers branch bottomlands.

\subsection{Upland contributions to bottomlands}

Uplands were contributors of flow to bottomlands during all seasons for all sites. Upland contributions declined throughout the year as water tables dropped (Fig. 6). Annual upland contributions were greatest in Meyers branch followed by Pen branch D. Fourmile creek and Pen branch $\mathrm{C}$ had the lowest upland inputs (Table 3 ).

\subsection{Bottomland contributions to streams}

On an annual basis, all bottomlands were sources of water to streams although seasonal variability was high (Table 3 , Fig. 7). Bottomland contributions to streamflow decrease throughout the year, and in some cases hydrologic gradients

Table 3

Annual water budget for Pen branch, Fourmile creek, and Meyers branch bottomlands including upland inputs (UP), throughfall inputs (TF), wetland losses to the stream (SL), ET losses (ET), water deficit (WD), and bottomland interflow (BI) ${ }^{\text {a.b }}$

\begin{tabular}{|c|c|c|c|c|c|c|c|}
\hline \multirow[t]{2}{*}{ Site } & \multicolumn{2}{|l|}{ Inputs } & \multicolumn{5}{|l|}{ Outputs } \\
\hline & $\mathrm{UP}\left(\mathrm{m}^{3}\right)$ & $\mathrm{TF}\left(\mathrm{m}^{3}\right)$ & $\mathrm{SL}\left(\mathrm{m}^{3}\right)$ & ET $\left(\mathrm{m}^{3}\right)$ & WD $\left(\mathrm{m}^{3}\right)$ & $\mathrm{BI}\left(\mathrm{m}^{3}\right)$ & Discharge status \\
\hline Pen branch $\mathrm{C}$ & $82.8 \mathrm{a}$ & 19.5 & $246 \mathrm{a}$ & $35.2 \mathrm{a}$ & 179 & 230 & GR \\
\hline Pen branch D & $108.2 \mathrm{~b}$ & 21.2 & $852 \mathrm{ab}$ & $18.9 \mathrm{~b}$ & 742 & 580 & GD \\
\hline Fourmile creek & $91.2 \mathrm{a}$ & 18.4 & $630 \mathrm{a}$ & $38.7 \mathrm{a}$ & 559 & 637 & GR \\
\hline
\end{tabular}

a If $\mathrm{WD}<\mathrm{BI}$, groundwater recharge (GR) is occurring, if $\mathrm{WD}>\mathrm{BI}$, groundwater discharge (GD) is occurring.

b Significant differences noted $(P<0.05)$. 
were reversed such as in Pen branch $\mathrm{C}$ and Fourmile creek during summer and fall indicating that the stream was a source of water to the bottomland (Fig. 7).

\subsection{Bottomland interflow}

Water tables within sites showed considerable hydrologic gradients from upstream to downstream in the bottomlands, indicating soil water interflow parallel to the floodplain corridor (Fig. 2). Soil water flow through the bottomland (interflow) varied throughout the year, increasing from winter to spring and decreasing throughout the remainder of the year (Fig. 8). Soil water fluxes from bottomland interflow were greatest in Meyers branch, followed by similar fluxes in Pen branch D and Fourmile creek bottomlands, with Pen branch $\mathrm{C}$ having the lowest fluxes (Table 3 ).

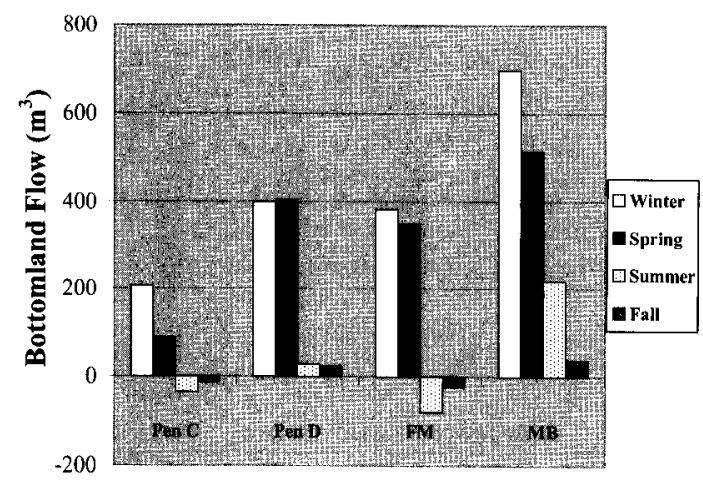

Fig. 7. Seasonal flow from bottomlands to Pen branch C, Pen branch D, Fourmile creek and Meyers branch streams.

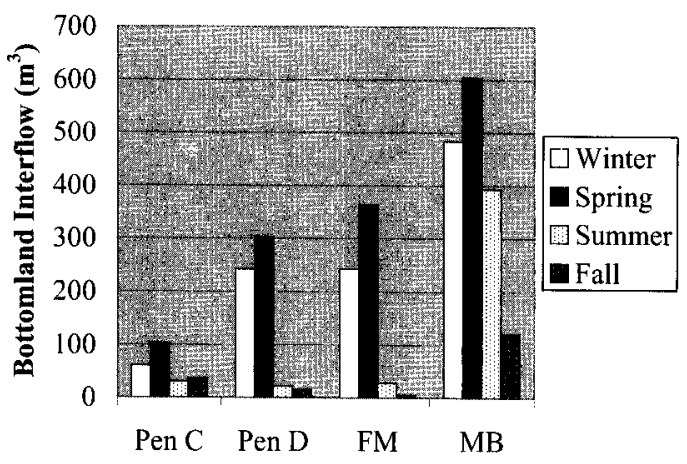

Fig. 8. Bottomland interflow through Pen branch C, Pen branch D, Fourmile creek and Meyers branch bottomlands.

\subsection{Annual water budgets}

Annual water budgets show deficits for all sites (i.e. outputs are greater than inputs) (Table 3). Deficits are compensated by bottomland interflow entering from above sites, flowing through and exiting from sites. Of course bottomland interflow entering a site may become part of ET or stream losses within a site but other sources such as throughfall and upland inputs may also add to interflow. When bottomland interflow cannot fully compensate for deficits, we have not fully accounted for all water sources. In contrary, when bottomland interflow is greater than deficits, we have not fully accounted for all water outputs. Deeper groundwater discharge/recharge is likely affecting the hydrologic budgets of these sites. Bottomland interflow is generally much greater than the water deficit in winter and spring during high water, the most likely time for deeper groundwater recharge to occur. As water tables fell during summer and fall, differences between interflow and the water deficit lessened and in many cases the water deficit was greater than interflow, indicating deeper groundwater discharge.

\section{Discussion}

Comparison of hydrologic budgets among sites assumes that Pen branch, Fourmile creek and Meyers branch had similar hydrology before disturbance. Although no records exist to assess this assumption, previous records of vegetation, an indicator of hydrologic character, indicate sites were at least similar in nature (Sharitz et al., 1974). Given that sites had similar hydrology before disturbance, the effect of succession and restoration can be evaluated.

In general, the hydrologic balance is very similar among sites in Pen branch and Fourmile creek, both early successional systems. Bottomland losses to the stream are similar among Fourmile creek and restored (Pen branch D) and unrestored sites (Pen branch C) in Pen branch (Table 3). Upland inputs in Pen branch $D$ are higher than those in Pen branch $\mathrm{C}$ and Fourmile 
probably as a result of higher water tables (Table 1) associated with lower slope gradients between uplands and bottomlands. Throughfall and ET differences in Pen branch D are due to the removal of the black willow (Salix nigra) canopy prior to planting. Site preparation (herbiciding and burning) has led to dense thickets of annual and perennial grasses and forbs such as blackberry (Rubus spp.) with virtually no canopy except for surviving scattered seedlings and some volunteer red maple (Acer rubrum). Pen branch C and Fourmile canopies are similar, both dominated by 9-13-year-old black willow, hence they have similar throughfall and ET. Although bottomland interflow is greater in Pen branch $\mathrm{D}$ and Fourmile creek than those in Pen branch C, these differences are offset by higher bottomland losses to the stream (Table 3).

Meyers branch had considerably different hydrology than the early successional systems. Meyers branch had significantly higher upland inputs, bottomland interflow, bottomland to stream losses and ET than sites in Pen branch and Fourmile creek (Table 3). Differences in ET can be directly attributed to canopy differences that have resulted from disturbance. Higher upland inputs, bottomland interflow and losses to the stream are a function of higher water tables present in both the upland and bottomland in Meyers branch (Table 1). Lower water table levels in the disturbed systems could be due to geomorphic alterations that occurred as a result of elevated flows. Although not well characterized, elevated flows in Pen branch and Fourmile creek caused severe erosion in the bottomland, depositing much of the organically rich, high water holding capacity topsoil in their respective deltas. Soil descriptions in Meyers branch typically had $\mathrm{O}+$ A horizons of greater than $20 \mathrm{~cm}$ whereas those in Pen branch and Fourmile creek were less than 10 $\mathrm{cm}$ and often less than $5 \mathrm{~cm}$. Elevation gradients also changed as a result of soil erosion. The calculated elevation gradient in Meyers branch was $0.058 \mathrm{~cm} \mathrm{~m}^{-1}$, which was considerably less than Fourmile creek $\left(0.32 \mathrm{~cm} \mathrm{~m}^{-1}\right)$ and Pen branch $\left(0.10 \mathrm{~cm} \mathrm{~m}^{-1}\right)$. Lower elevation gradients and loss of high water holding capacity topsoil could explain some of the differences in water table elevation between the disturbed sites and the reference site. Meyers branch simply has more dynamic hydrology than the disturbed sites, with greater fluctuations in the water table and more frequent flooding.

Although we characterized flow paths in the terrestrial bottomland zone, streamflow is the dominant hydrologic flux in all systems, being one to two orders of magnitude greater, on a volume basis, than any of the terrestrial fluxes in Table 3 . Walton et al. (1996) found a similar difference in magnitude between streamflow and rainfall, ET, and groundwater discharge for a bottomland hardwood system along the Cache river in Arkansas (Walton et al., 1996).

\section{Conclusions}

The hydrologic budget of four bottomland hardwood sites was characterized. Sites included a recently restored bottomland, two sites that were disturbed, but are recovering naturally and a mature reference site. The recently restored site and the two sites that are recovering naturally had similar hydrology, with notable differences in throughfall and ET attributed to the alteration of the canopy associated with restoration. The reference site had significantly different volumes of flow associated with most of the major flow pathways. Throughfall and ET differences between the reference site and the early successional sites are attributed to canopy differences. Terrestrial flow pathway differences are speculated to be the result of geomorphic changes that occurred as a result of elevated flows during disturbance. Although terrestrial hydrologic fluxes are important determinants to assess the effect of restoration on the functional recovery of hydrology, streamflow is the dominant flux of water in all four sites.

\section{Acknowledgements}

The authors would like to thank Frederick James, Amy Bergstedt, Abby van den Berg, Mylessia Quillen, and Harry James for help with field work and collection of data. 


\section{References}

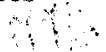

Aust, W.M., Schoenholtz, S.H., Zaebst, T.W., Szabo, B.A., 1997. Recovery status of a tupelo-cypress wetland seven years after disturbance: silvicultural implications. Forest Ecol. Manage. 90, 161-169.

Clewell, A.F., Lea, R., 1989. Creation and restoration of forested wetland vegetation in the southeastern United States. In: Kusler, J.A., Kentula, M.E. (Eds.), Wetland Creation and Restoration: The Status of the Science. Island Press, Washington, DC, pp. 195-232.

Comerford, N.B., Jerez, A., Freitas, A.A., Montgomery, J., 1996. Soil water table, reducing conditions, and hydrologic regime in a Florida flatwood landscape. Soil Sci. 161 (3), 194-199.

Conner, W.H., Day, J.W. Jr, 1991. Leaf litter decomposition in three Louisiana freshwater forested wetland areas with different flooding regimes. Wetlands 11 (2), 303-312.

David, P.G., 1996. Changes in plant communities relative to hydrologic conditions in the Florida Everglades. Wetlands 16 (1), 15-23.

Dosskey, M.G., Bertsch, P.M., 1994. Forest sources and pathways of organic matter transport to a blackwater stream: a hydrologic approach. Biogeochemistry 24, 1-19.

Dulohery, N.C., Kolka, R.K., McKevlin, M.R., 2000. Effects of a willow overstory on planted seedlings in a bottomland restoration. Ecol. Eng.

Lockaby, B.G., Jones, R.H., Clawson, R.G., Meadows, J.S., Stanturf, J.A., Thornton, F.C., 1997. Influences of harvesting on functions of floodplain forests associated with loworder, blackwater streams. Forest Ecol. Manage. 90, $217-224$.
Megonigal, J.P., Patrick, W.H., Faulkner, S.P., 1993. Wetland identification in seasonally flooded forest soils: soil morphology and redox dynamics. Soil Sci. Soc. Am. J. 57, 140-149.

Mitsch, W.J., Gosselink, J.G., 1993. Wetlands, second ed. Van Nostrand Reinhold, New York, p. 722.

Myers, R.S., Shaffer, G.P., Llewellyn, D.W., 1995. Baldcypress restoration in Southeast Louisiana: the relative effects of herbivory, flooding, competition, and macronutrients. Wetlands 15 (2), 141-148.

Nelson, E.A., Dulohery, N.C., Kolka, R.K., 2000. Operational restoration of the Pen Branch bottomland hardwood and swamp wetlands. Ecol. Eng.

Niswander, S.F., Mitsch, W.J., 1995. Functional analysis of a two-year-old created in-stream wetland: hydrology, phosphorus retention, and vegetation survival and growth. Wetlands 15 (3), 212-225.

Sharitz, R.R., Irwin, J.E., Christy, E.J., 1974. Vegetation of swamps receiving reactor effluents. Oikos 25, 7-13.

Walton, R., Davis, J.E., Martin, T.H., Chapman, R.S., 1996. Hydrology of the Black Swamp wetlands on the Cache River, Arkansas. Wetlands 16 (3), 279-287.

Westinghouse Savannah River Company, 1997. SRS Ecology: Environmental Information Document. In: Halverson, N.V., Patterson, K.K. (Eds.), WSRC-TR-97-0223.

Williams, J.B., Pinder, J.E. III, 1990. Ground water flow and runoff in a coastal plain stream. Water Resour. Bull. 26 (2), $343-352$.

Wilson, R.F., Mitsch, W.J., 1996. Functional assessment of five wetlands constructed to mitigate wetland loss in Ohio. Wetlands 16 (4), 436-451.

Workman, S.W., McLeod, K.W., 1990. Vegetation of the Savannah river site: major community types. Savannah River Site-National Environmental Research Park Publication 19, Aiken, SC, 137 pp. 